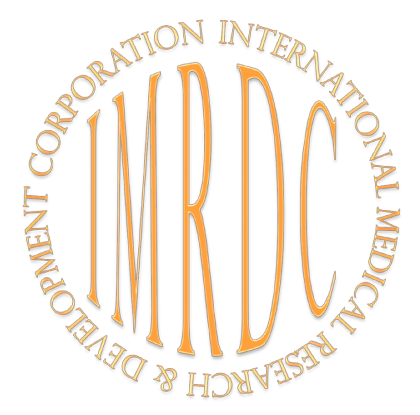

\title{
Evolution of the Structure of Children's Morbidity Rate in the Republic of Sakha (Yakutia)
}

\author{
Tatyana E. Burtseva, PhD, ScD ${ }^{1,2^{*}}$; Sardana A. Evseeva ${ }^{2}$; Maya S. Savvina, $\mathrm{PhD}^{2}$; \\ Svetlana Y.Yakovleva, $\mathrm{PhD}^{2}$; Vyacheslav G. Chasnyk, $\mathrm{PhD}, \mathrm{ScD}^{3}$ \\ ${ }^{\prime}$ M. K. Ammosov North-Eastern Federal University, Yakutsk, Russia \\ ${ }^{2} Y a k u t$ Science Center of Complex Medical Problems, Yakutsk, Russia \\ ${ }^{3}$ Saint Petersburg State Pediatric Medical University, St. Petersburg, Russia
}

\begin{abstract}
Currently, the comparative studies of human health status definitely show that the health level of a population has a regional specificity. This paper analyzes the data of official medical statistics on morbidity among the child population in dynamics from 2000 to 2016 and presents the evolution of the children's incidence structure in the Republic of Sakha (Yakutia) (RS(Y)), according to ICD-10.(International Journal of Biomedicine. 2018;8(1):47-50.)
\end{abstract}

Key words: children's incidence $\bullet$ children $\bullet$ adolescents $\bullet$ Yakutia

\section{Introduction}

In order to improve child protective measures, the years 2018-2027 in Russia were declared as the Decade of Childhood. At the same time, the regions of Russia differ greatly in their socioeconomic, climatogeographic, and medico-demographic parameters, and in their medical care structure, communication, and transport development, all of which definitely affects the costs and effectiveness of the health care system.

The impact of extreme climatogeographic and socioeconomic features in the North is reflected in the unfavorable dynamic changes in the health of the younger generation. ${ }^{(1-6)}$ The indicators of the overall incidence among children in the regions of the Far North for some classes of diseases exceed the average federal level by approximately 1.5-2 times. ${ }^{(1,3)}$

The aim of this study was to analyze the data of official medical statistics on morbidity among the child population in dynamics from 2000 to 2016 and to present the evolution of the children's incidence structure in $\mathrm{RS}(\mathrm{Y})$, according to ICD-10.

*Corresponding author: Tatiana E. Burtseva, PhD, ScD. M.K. Ammosov North-Eastern Federal University, Yakutsk, Russia. E-mail: bourtsevat@yandex.ru

\section{Materials and Methods}

We analyzed the data of the official statistics of RS(Y) on the child incidence in dynamics from 2000 to 2016 . We calculated the increase and decrease in morbidity (in percent) in order to present the evolution of children's incidence structure in the RS(Y) for 17 years.

\section{Results}

On 01/01/16, the population of RS(Y) numbered 959,600 people, including 258,200 children and adolescents. Thus, the share of children and adolescents was $27 \%$. The demographic situation in RS(Y) at the end of 2016 was characterized by the stable rates of birth $(16 \%)$, total mortality $(8.4 \%)$ and natural increase $(7.6 \%)$. The infant mortality rate for the period 2000 2016 exceeded the all-Russian rate. However, it had decreased by 2.5 times in dynamics since 2000 and reached a historic low of $6.8 \%$ in 2016 . There were no maternal deaths for the first time in 2016

The total and primary child incidence in $\mathrm{RS}(\mathrm{Y})$ remains at a high level, exceeding the average rate for the Russian Federation, and grows annually, which is associated with both a real deterioration in the health status of children and adolescents, and with an increase in the availability of medical services and the quality of medical examinations. 
The total children's incidence in 2016 was 2774.4 per 1,000 children (0-14 years) compared to 2773.3 per 1,000 in 2015 . Table 1 shows the significant changes in total children's incidence in SR(Y) in 2000-2017. In general, the morbidity rate had risen by $70.8 \%$. The most significant increase was found in the following disease classes: neoplasm (229.5\%), the musculoskeletal system diseases $(127.8 \%)$, the digestive system diseases (123.3\%), and congenital anomalies $(122.1 \%)$. The reduction in this indicator was noted for such disease classes as: endocrine system diseases, infectious and parasitic diseases, mental and behavioural disorders.

Table 1.

The total children's incidence in SR(Y) (per 1,000 children of 0-14 years)

\begin{tabular}{|c|c|c|c|}
\hline $\begin{array}{l}\text { Disease classes } \\
\text { ICD-10 }\end{array}$ & 2000 & 2016 & $\begin{array}{c}\text { Rate of } \\
\text { increase/ } \\
\text { decrease, } \%\end{array}$ \\
\hline Total & 1623.6 & 2774.4 & +70.8 \\
\hline $\begin{array}{l}\text { Certain infectious and parasitic } \\
\text { diseases }\end{array}$ & 105.8 & 74.7 & -29.4 \\
\hline Neoplasms & 4.4 & 14.5 & +229.5 \\
\hline $\begin{array}{l}\text { Diseases of the blood and blood- } \\
\text { forming organs and certain disorders } \\
\text { involving the immune mechanism }\end{array}$ & 19.3 & 21.1 & +9.3 \\
\hline $\begin{array}{l}\text { Endocrine. nutritional and metabolic } \\
\text { diseases }\end{array}$ & 43.5 & 25.6 & -41.2 \\
\hline Mental and behavioural disorders & 18.6 & 13.3 & -28.5 \\
\hline Diseases of the nervous system & 88.7 & 126.4 & +42.5 \\
\hline Diseases of the eye and adnexa & 79.5 & 127.8 & +60.7 \\
\hline $\begin{array}{l}\text { Diseases of the ear and mastoid } \\
\text { process }\end{array}$ & 29.0 & 51.3 & +76.9 \\
\hline Diseases of the circulatory system & 6.9 & 13.5 & +95.6 \\
\hline Diseases of the respiratory system & 897.7 & 1724.3 & +92.0 \\
\hline Diseases of the digestive system & 95.6 & 213.5 & +123.3 \\
\hline $\begin{array}{l}\text { Diseases of the skin and subcutaneous } \\
\text { tissue }\end{array}$ & 80.8 & 123.7 & +53.1 \\
\hline $\begin{array}{l}\text { Diseases of the musculoskeletal } \\
\text { system and connective tissue }\end{array}$ & 16.9 & 38.5 & +127.8 \\
\hline Diseases of the genitourinary system & 29.0 & 49.9 & +72.0 \\
\hline $\begin{array}{l}\text { Congenital malformations. } \\
\text { deformations and chromosomal } \\
\text { abnormalities }\end{array}$ & 14.0 & 31.1 & +122.1 \\
\hline $\begin{array}{l}\text { Symptoms. signs and abnormal } \\
\text { clinical and laboratory findings. not } \\
\text { elsewhere classified }\end{array}$ & 0 & 82.2 & $\ldots$ \\
\hline $\begin{array}{l}\text { Injury, poisoning and certain other } \\
\text { consequences of external causes }\end{array}$ & 59.3 & 106.3 & +79.2 \\
\hline
\end{tabular}

The primary child morbidity rate increased in 2016 by $5.4 \%$, amounting to 2338.3 per 1,000 children (vs. 2218.5 in 2015). During the study period, this rate increased by
$73.3 \%$. We noted the greatest increase for such disease classes as congenital malformations $(276.0 \%)$, neoplasms $(187.5 \%)$, respiratory diseases $(98.8 \%)$, digestive system diseases $(93.3 \%)$, genitourinary system diseases $(75,8 \%)$, the musculoskeletal system diseases (61.7\%), and nervous system diseases $(61.7 \%)$ on the background of a decrease in such disease classes as endocrine system diseases, mental and behavioural disorders, infectious and parasitic diseases, and blood and blood-forming organ diseases.

Table 2.

The primary children's incidence in $S R(Y)$ (per 1.000 children of 0-14 years)

\begin{tabular}{|c|c|c|c|}
\hline $\begin{array}{l}\text { Disease classes } \\
\text { ICD-10 }\end{array}$ & 2000 & 2016 & $\begin{array}{c}\text { Rate of } \\
\text { increase } \\
\text { decrease. } \\
\%\end{array}$ \\
\hline Total & 1348.7 & 2338.3 & +73.3 \\
\hline $\begin{array}{l}\text { Certain infectious and parasitic } \\
\text { diseases }\end{array}$ & 86.7 & 67.0 & -22.7 \\
\hline Neoplasms & 2.4 & 6.9 & +187.5 \\
\hline $\begin{array}{l}\text { Diseases of the blood and blood- } \\
\text { forming organs and certain disorders } \\
\text { involving the immune mechanism }\end{array}$ & 10.3 & 8.1 & -21.3 \\
\hline $\begin{array}{l}\text { Endocrine. nutritional and metabolic } \\
\text { diseases }\end{array}$ & 19.5 & 6.8 & -65.1 \\
\hline Mental and behavioural disorders & 4.8 & 2.1 & -56.2 \\
\hline Diseases of the nervous system & 24.8 & 40.1 & +61.7 \\
\hline Diseases of the eye and adnexa & 50.8 & 70.0 & +37.8 \\
\hline $\begin{array}{l}\text { Diseases of the ear and mastoid } \\
\text { process }\end{array}$ & 31.5 & 40.3 & +27.9 \\
\hline Diseases of the circulatory system & 4.3 & 6.2 & +44.1 \\
\hline Diseases of the respiratory system & 831.0 & 1653.0 & +98.9 \\
\hline Diseases of the digestive system & 77.9 & 150.6 & +93.3 \\
\hline $\begin{array}{l}\text { Diseases of the skin and subcutaneous } \\
\text { tissue }\end{array}$ & 71.3 & 96.3 & +35.1 \\
\hline $\begin{array}{l}\text { Diseases of the musculoskeletal } \\
\text { system and connective tissue }\end{array}$ & 16.2 & 26.2 & +61.7 \\
\hline Diseases of the genitourinary system & 17.4 & 30.6 & +75.8 \\
\hline $\begin{array}{l}\text { Congenital malformations. } \\
\text { deformations and chromosomal } \\
\text { abnormalities }\end{array}$ & 2.5 & 9.4 & +276.0 \\
\hline $\begin{array}{l}\text { Symptoms. signs and abnormal } \\
\text { clinical and laboratory findings. not } \\
\text { elsewhere classified }\end{array}$ & $\ldots$ & 0.2 & $\ldots$ \\
\hline $\begin{array}{l}\text { Injury. poisoning and certain other } \\
\text { consequences of external causes }\end{array}$ & 67.4 & 106.2 & +57.5 \\
\hline
\end{tabular}

The total adolescent morbidity rate decreased in 2016 by $4.6 \%$ from 2390.8 to 2280.7 per 1,000 adolescents. The Table 3 shows that the total incidence rate in adolescents had no significant changes in 2000-2016. We noted the most significant increase for such disease classes as neoplasms $(358.3 \%)$, the musculoskeletal system disease (169.7\%), respiratory diseases 
(164.4\%), ear and mastoid disease (163\%), on the background of a decrease in such disease classes as nervous system diseases, infectious and parasitic diseases, diseases of the endocrine system.

Table 3.

The total adolescent morbidity rate in $\mathrm{RS}(Y) \mathrm{c}$ (per 1000 adolescents)

\begin{tabular}{|c|c|c|c|}
\hline $\begin{array}{l}\text { Disease classes } \\
\text { ICD-10 }\end{array}$ & 2000 & 2016 & $\begin{array}{c}\text { Rate of } \\
\text { increase/ } \\
\text { decrease. } \\
\%\end{array}$ \\
\hline Total & 1089.8 & 2280.7 & +109.2 \\
\hline $\begin{array}{l}\text { Certain infectious and parasitic } \\
\text { diseases }\end{array}$ & 42.6 & 36.9 & -13.3 \\
\hline Neoplasms & 2.4 & 11.0 & +358.3 \\
\hline $\begin{array}{l}\text { Diseases of the blood and blood- } \\
\text { forming organs and certain disorders } \\
\text { involving the immune mechanism }\end{array}$ & $\ldots$ & 27.6 & $\ldots$ \\
\hline $\begin{array}{l}\text { Endocrine. nutritional and metabolic } \\
\text { diseases }\end{array}$ & 66.7 & 62.4 & -6.4 \\
\hline Mental and behavioural disorders & 34.7 & 33.5 & -3.4 \\
\hline Diseases of the nervous system & 222.7 & 168.4 & -24.3 \\
\hline Diseases of the eye and adnexa & $\ldots$ & 210.1 & $\cdots$ \\
\hline Diseases of the ear and mastoid process & 14.6 & 38.4 & +163.0 \\
\hline Diseases of the circulatory system & 21.8 & 37.6 & +72.4 \\
\hline Diseases of the respiratory system & 346.1 & 915.3 & +164.4 \\
\hline Diseases of the digestive system & 103.7 & 242.0 & +133.3 \\
\hline $\begin{array}{l}\text { Diseases of the skin and subcutaneous } \\
\text { tissue }\end{array}$ & 58.9 & 133.8 & +127.1 \\
\hline $\begin{array}{l}\text { Diseases of the musculoskeletal } \\
\text { system and connective tissue }\end{array}$ & 27.8 & 75.0 & +169.7 \\
\hline Diseases of the genitourinary system & 58.4 & 70.32 & +20.3 \\
\hline $\begin{array}{l}\text { Congenital malformations. } \\
\text { deformations and chromosomal } \\
\text { abnormalities }\end{array}$ & 13.1 & 17.3 & +32.0 \\
\hline $\begin{array}{l}\text { Symptoms. signs and abnormal clinical } \\
\text { and laboratory findings. not elsewhere } \\
\text { classified }\end{array}$ & $\ldots$ & 0.1 & $\ldots$ \\
\hline $\begin{array}{l}\text { Injury. poisoning and certain other } \\
\text { consequences of external causes }\end{array}$ & 76.3 & 190.5 & +149.6 \\
\hline
\end{tabular}

The primary incidence rate in adolescents in 2016 was reduced to $2 \%$. The rate of primary incidence among adolescents increased in $2000-2016$ by $94 \%$ (Table 4 ).

The reduction in the primary incidence was noted for such diseases as mental and behavioral disorders, congenital anomalies. We noted the most significant increase for such disease classes as the digestive system diseases (169.5\%), injury and poisoning (141.5\%), the respiratory system diseases (138.6\%), the nervous system diseases (120.4\%), the musculoskeletal system diseases (112.4\%), diseases of the circulatory system $(112.9 \%)$.
Table 4.

The primary incidence rate in adolescents in SR(Y) (per 1000 adolescents)

\begin{tabular}{|c|c|c|c|}
\hline $\begin{array}{l}\text { Disease classes } \\
\text { ICD-10 }\end{array}$ & 2000 & 2016 & $\begin{array}{c}\text { Rate of } \\
\text { increase/ } \\
\text { decrease. } \\
\%\end{array}$ \\
\hline Total & 784.5 & 1522.1 & +94.0 \\
\hline Certain infectious and parasitic diseases & 35.4 & 29.2 & +17.5 \\
\hline Neoplasms & 2.0 & 3.3 & +65.0 \\
\hline $\begin{array}{l}\text { Diseases of the blood and blood- } \\
\text { forming organs and certain disorders } \\
\text { involving the immune mechanism }\end{array}$ & 8.6 & 9.2 & +6.9 \\
\hline $\begin{array}{l}\text { Endocrine. nutritional and metabolic } \\
\text { diseases }\end{array}$ & 32.8 & 12.1 & +63.1 \\
\hline Mental and behavioural disorders & 20.2 & 6.0 & -70.3 \\
\hline Diseases of the nervous system & 25.4 & 56.0 & +120.4 \\
\hline Diseases of the eye and adnexa & 49.6 & 60.6 & +22.1 \\
\hline Diseases of the ear and mastoid process & 15.1 & 23.9 & +58.2 \\
\hline Diseases of the circulatory system & 7.7 & 16.4 & +112.9 \\
\hline Diseases of the respiratory system & 343.8 & 820.4 & +138.6 \\
\hline Diseases of the digestive system & 49.3 & 132.9 & +169.5 \\
\hline $\begin{array}{l}\text { Diseases of the skin and subcutaneous } \\
\text { tissue }\end{array}$ & 53.6 & 81.8 & +52.6 \\
\hline $\begin{array}{l}\text { Diseases of the musculoskeletal system } \\
\text { and connective tissue }\end{array}$ & 16.9 & 35.9 & +112.4 \\
\hline Diseases of the genitourinary system & 30.7 & 35.4 & +15.3 \\
\hline $\begin{array}{l}\text { Congenital malformations. } \\
\text { deformations and chromosomal } \\
\text { abnormalities }\end{array}$ & 13.4 & 1.5 & -88.8 \\
\hline $\begin{array}{l}\text { Symptoms. signs and abnormal clinical } \\
\text { and laboratory findings. not elsewhere } \\
\text { classified }\end{array}$ & 2.7 & 0.02 & -99.2 \\
\hline $\begin{array}{l}\text { Injury. poisoning and certain other } \\
\text { consequences of external causes }\end{array}$ & 78.7 & 190.1 & +141.5 \\
\hline
\end{tabular}

\section{Conclusion}

In recent years, there has been an annual reduction in child population in $\mathrm{RS}(\mathrm{Y})$ due to migration and a decrease in the birth rate. So, 301,800 children (from 0 to 17 years) lived in $\mathrm{RS}(\mathrm{Y})$ in 2000 , but the number of children was reduced to 258,200 by 2016 . It is obvious that the general and primary incidence in the child and adolescent population is increasing in $\mathrm{RS}(\mathrm{Y})$. The structure of the children and adolescent incidence has changed significantly. The primary incidence of infectious and parasitic diseases has clearly decreased due to widespread vaccination efforts against controlled infections. The increase in the primary incidence of congenital anomalies and neoplasms in child population is very worrying. The difficult climatic conditions of this northern territory cause a high primary incidence among children of respiratory diseases and genitourinary system diseases. In addition, changing the 
traditional diet has led to an increase in digestive system diseases. All this dictates the necessity for a complex and interdepartmental approach to strengthening the health of the younger generation in $\mathrm{RS}(\mathrm{Y})$.

\section{Competing interests} interests.

The authors declare that they have no competing

\section{References}

1. Egorova VB, Savvina NV, Munkhalova YA, Dmitrieva TG, Markova SV, Artamonova SU. Health state of adolescents in the Republic Sakha (Yakutia).Wiad Lek. 2016;69(1 Pt 2):64-8.

2. Baisheva NS, Douglas NI, Pavlova TY, Yakovleva AI,
Burtseva TE. The Outcomes of Very Early Preterm Births in the Republic of Sakha (Yakutia). International Journal of Biomedicine. 2016; 6(1):56-59.

3. Orel V.I., Okhlopkov M.E., Grigor'eva A.N., Burtseva T.E., Chasnyk V.G., Sereda V.M., et al. Children of the Arctic: dynamics of medico-demographic indicators. Pediatrician (St. Peresburg).2017;8(6):30-37.[Article in Russian].

4. Shadrin VP, Burtseva TY, Avrusin SL, Solodkova IV. Climate change, human health and well-being in Yakutia. Pediatrician (St.Peresburg). 2014;5(4):70-76.[Article in Russian].

5. Baranov AA, Il'in AG. [Actual problems of preservation and strengthening of children's health in the Russian Federation]. Russian Pediatric Journal. 2011;(4):7-12.[Article in Russian].

6. Tyrylgin MA. The health protection problems of the Far North population (by the example of the Yakutia region. Novosibirsk: Nauka; 2008. [in Russian]. 